\title{
Catalytic Mechanism of S-Ribosylhomocysteinase (LuxS): Direct Observation of Ketone Intermediates by ${ }^{13} \mathrm{C}$ NMR Spectroscopy
}

\section{(Supporting Information)}

\author{
Jinge Zhu, Xubo Hu, Eric Dizin, and Dehua Pei*
}

Materials. $\left[2-{ }^{13} \mathrm{C}\right]$ Adenosine and $\left[3-{ }^{13} \mathrm{C}\right]$ adenosine were purchased from Omicron Biochemicals, Inc. (South Bend, IN). L-4,4'-Dithio-bis(2-aminobutanoic acid) was purchased from Bachem (King of Prussia, PA). 1,4-Dithio-DL-threitol (DTT) solution was from New England Biolabs (Beverly, MA). All other chemicals were purchased from Sigma-Aldrich. Nucleosidase Pfs and wild-type and mutant Co(II)-substituted LuxS, both from Bacillus subtilis, were overexpressed in Escherichia coli and purified to near homogeneity as previously described. ${ }^{[1]}$

Purification of SAH Hydrolase (SAHH). E. coli BL21(DE3) cells (2L) carrying the plasmid pPROK-1 SAHH (kindly provided by Dr. Michael Hershfield of Duke University) were grown in LB medium supplemented with $75 \mathrm{mg} / \mathrm{L}$ ampicillin at $37{ }^{\circ} \mathrm{C}$ to an $\mathrm{OD}_{600}$ of 0.6 . The cells were induced by the addition of $100 \mu \mathrm{M}$ isopropyl- $\beta$-Dthiogalactoside and grown at $30{ }^{\circ} \mathrm{C}$ for an additional $5 \mathrm{~h}$. Cells were harvested by centrifugation and resuspended in $70 \mathrm{~mL}$ of a lysis buffer containing $20 \mathrm{mM}$ MES (pH 6.0), $10 \mathrm{mM} \mathrm{NaCl}, 1 \%$ Triton $\mathrm{X}-100,0.5 \%$ protamine sulfate, $20 \mu \mathrm{g} / \mathrm{mL}$ trypsin inhibitor, $50 \mu \mathrm{g} / \mathrm{mL}$-methylbenzenesulfonyl fluoride and $70 \mu \mathrm{g} / \mathrm{mL}$ chicken eggwhite lysozyme with stirring for $20 \mathrm{~min}$ at $4{ }^{\circ} \mathrm{C}$, followed by brief sonication and centrifugation. The supernatant was loaded on an SP-Sepharose Fast-Flow column (3 x 9 $\mathrm{cm}$; Amersham Pharmacia Biotech AB) equilibrated in $20 \mathrm{mM}$ MES (pH 6.0) and $10 \mathrm{mM}$ $\mathrm{NaCl}$. The flow-through fraction was collected and loaded on a Q-Sepharose Fast-Flow column (3 x $8 \mathrm{~cm}$; Amersham Pharmacia Biotech AB) that had been pre-equilibrated with $25 \mathrm{mM}$ Tris ( $\mathrm{pH} \mathrm{8.0)}$ ) and $20 \mathrm{mM} \mathrm{NaCl}$. After being washed with 3 column volumes of the equilibrating buffer, the column was eluted with a $\mathrm{NaCl}$ gradient $(20-500 \mathrm{mM})$ in the same buffer. The fractions enriched in SAHH (as analyzed by SDS-PAGE; containing $130 \mathrm{mM} \mathrm{NaCl}$ ) were pooled $(30 \mathrm{~mL})$, adjusted to $1 \mathrm{M} \mathrm{NaCl}$, and loaded on a PhenylSepharose Fast-Flow column $(3 \times 9 \mathrm{~cm}$; Amersham Pharmacia Biotech AB). After gentle washing $(50 \mathrm{~mL}$ of Tris, $\mathrm{pH} 8.0$ and $1 \mathrm{M} \mathrm{NaCl})$, SAHH was eluted with a reverse gradient of 1,000-10 $\mathrm{mM} \mathrm{NaCl}$ in the above buffer (SAHH eluted at $850 \mathrm{mM} \mathrm{NaCl}$ ). The protein was then concentrated in an Amicon apparatus (Millipore), quickly frozen in dry ice-isopropanol, and stored at $-80{ }^{\circ} \mathrm{C}$. Protein concentration was determined by the Bradford method using bovine serum albumin (Sigma) as standard.

Preparation of $\left[2-{ }^{13} \mathrm{C}\right] \mathrm{SRH}$ and $\left[3-{ }^{13} \mathrm{C}\right] \mathrm{SRH}$. Figure 4 shows the reactions involved in the enzymatic synthesis of these substrates. L-4,4'-Dithio-bis(2-aminobutanoic acid) was reduced with one equivalent of DTT at $\mathrm{pH} 12$ for $3.5 \mathrm{~h}$. The crude homocysteine $(8$ $\mathrm{mM})$ was added to ${ }^{13} \mathrm{C}$-labeled adenosine $(8 \mathrm{mM})$ in a buffer containing $50 \mathrm{mM}$ $\mathrm{NaH}_{2} \mathrm{PO}_{4}-\mathrm{Na}_{2} \mathrm{HPO}_{4}(\mathrm{pH} 7.0)$ and $50 \mathrm{mM} \mathrm{NaCl}$, followed by the addition of SAHH (4 $\mu \mathrm{M})$. After overnight incubation at room temperature, an aliquot of the reaction mixture 

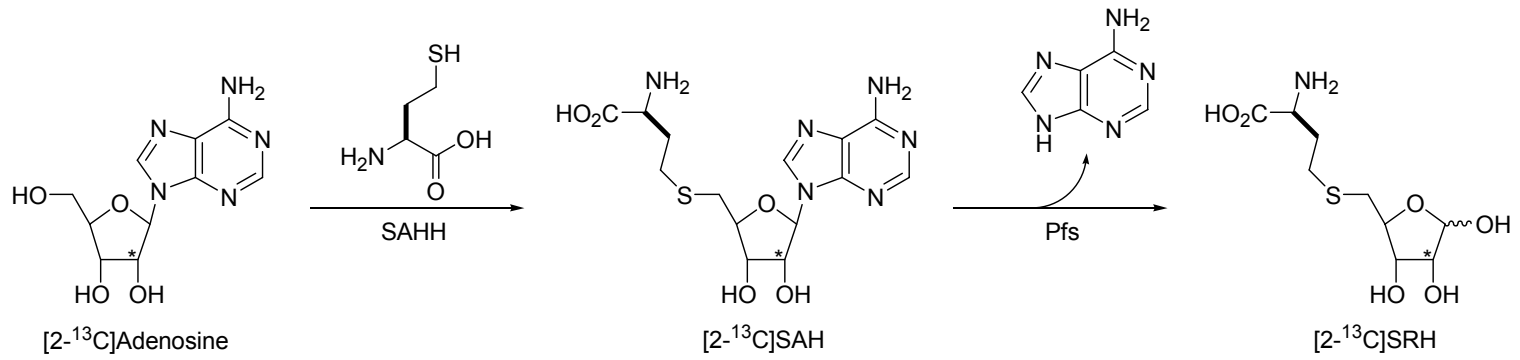

Figure 4. Enzymatic synthesis of $2-{ }^{13} \mathrm{C}$-labeled SRH.

was withdrawn and analyzed by reverse-phase HPLC on a semipreparative C18 column (Vydac ${ }^{\mathrm{TM}}$ ). The column was eluted with a 30-min linear gradient of 10-100 \% acetonitrile in water (monitored at $260 \mathrm{~nm}$ ). A sharp peak with $>90 \%$ purity appeared at $6.8 \mathrm{~min}$ (pure SAH eluted at 6.5 min under the same condition). Pfs $(5 \mu \mathrm{M})$ was then added, and reaction was incubated overnight. The conversion of SAH to SRH was checked based on the absorption difference between SAH and adenosine $\left(\Delta \varepsilon_{276}=-1.4 \mathrm{mM}^{-1} \mathrm{~cm}^{-1}\right) \cdot{ }^{[2]}$ Prior to use, the crude SRH was passed through a PrepSep ${ }^{\text {TM}}-\mathrm{C} 18$ extraction column (Fisher) for as least three times.

${ }^{13}$ C NMR Spectroscopy. Wild-type and mutant Co-LuxS was dialyzed against a buffer containing $50 \mathrm{mM} \mathrm{NaH}_{2} \mathrm{PO}_{4}-\mathrm{Na}_{2} \mathrm{HPO}_{4}(\mathrm{pH} 7.0)$ and $50 \mathrm{mM} \mathrm{NaCl}$ at $4{ }^{\circ} \mathrm{C}$ for $22 \mathrm{~h}$ with four changes of the buffer and concentrated in an Amicon apparatus (Millipore) to $\sim 5 \mathrm{mM}$. The LuxS reaction was initiated by mixing Co-LuxS (typically $2 \mathrm{mM}$ ) and an equal amount of ${ }^{13} \mathrm{C}$-SRH in the above buffer plus $10 \% \mathrm{D}_{2} \mathrm{O}\left(\right.$ at $\left.4{ }^{\circ} \mathrm{C}\right)$ and monitored on a Bruker DRX $600 \mathrm{MHz}$ instrument. For the experiment with different LuxS/SRH stoichiometry, the final concentration of $\left[2-{ }^{13} \mathrm{C}\right] \mathrm{SRH}$ was $5 \mathrm{mM}$ and the concentrations of wild-type Co-LuxS were $2.5 \mathrm{mM}$ for 1:2 ratio, $1.25 \mathrm{mM}$ for 1:4 ratio and $0.62 \mathrm{mM}$ for 1:8 ratio, respectively. Spectra were recorded every $10 \mathrm{~min}$.

Trapping of 2-Ketone Intermediate. The reaction of $\left[2-{ }^{13} \mathrm{C}\right] \mathrm{SRH}(2.1 \mathrm{mM})$ catalyzed by E57D mutant Co-LuxS $(1 \mathrm{mM})$ was allowed to proceed for $35 \mathrm{~min}$ at room temperature in a buffer $(800 \mu \mathrm{L})$ containing $50 \mathrm{mM} \mathrm{NaH}_{2} \mathrm{PO}_{4}-\mathrm{Na}_{2} \mathrm{HPO}_{4}(\mathrm{pH} 7.0)$ and 50 $\mathrm{mM} \mathrm{NaCl}$. The reaction was then quenched by the addition of methanol $(3 \mathrm{~mL})$. The precipitate was spun down and methanol was evaporated under reduced pressure. The clear solution was adjusted to $\mathrm{pH} 4.5$ and treated with a large excess of $\mathrm{NH}_{2} \mathrm{OH}(\sim 100$ $\mathrm{mM}$ ) for $>24 \mathrm{~h}$. The resulting solution was directly analyzed by ${ }^{13} \mathrm{C}$ NMR spectroscopy.

Pulse-Chase Experiment. For pulse-chase experiment, $2 \mathrm{mM}\left[2-{ }^{13} \mathrm{C}\right] \mathrm{SRH}$ and $2 \mathrm{mM}$ wild-type Co-LuxS were mixed and ${ }^{13} \mathrm{C}$ NMR spectrum was acquired for $30 \mathrm{~min}$. At this point, a highly concentrated unlabeled SRH solution was added to the reaction to make the final concentration of SRH $\sim 9 \mathrm{mM}$ and spectra were acquired every $25 \mathrm{~min}$.

Cloning of Vibrio harveyi LuxS and Site-Directed Mutagenesis. The gene coding for $V$. harveyi LuxS was cloned by using the polymerase chain reaction (PCR) with genomic DNA as template (kindly provided by Dr. Richard Sayre, Ohio State University) and primers 5'-GGAAGGCCATATGCCTTTATTAGACAGCTTTACC-3' and 5'- 
GGATCCTCGAGGTCGATGCGTAGCTCTCTCAG-3'. The PCR product was digested with restriction endonucleases $\mathrm{NdeI}$ and $\mathrm{XhoI}$ and cloned into the prokaryotic expression vector $\mathrm{pET} 22 \mathrm{~b}(+)$ (Novagen, WI) to generate the plasmid pET22b-luxS-HT. This cloning procedure resulted in the addition of a C-terminal histidine tag (HT). Site-directed mutagenesis was carried out on the plasmid pET22b-luxS-HT using the QuikChange mutagenesis kit (Stratagene, CA). The primers used for mutagenesis were as follows:

\section{C83A, 5'-ATCTCACCAATGGGGGCCCGTACTGGTTTCTACATGA-3'; C83S, 5'-ATCTCACCAATGGGGTCCCGTACTGGTTTCTACATGA-3'; C83D, 5'-ATCTCACCAATGGGGGACCGTACTGGTTTCTACATGA-3'; E57D, 5'-AAAGGAATTCATACATTAGATCATTTGTACGCAGGCA-3'; E57Q, 5'-AAAGGAATTCATACATTACAGCATTTGTACGCAGGCA-3'; E57A, 5'-AAAGGAATTCATACATTAGCGCATTTGTACGCAGGCA-3'.}

The identity of all DNA constructs was confirmed by DNA sequencing.

Purification of $\boldsymbol{V}$. harveyi LuxS. Escherichia coli BL21(DE3) cells (4 L) carrying the proper plasmid DNA were grown in LB medium supplemented with $75 \mathrm{mg} / \mathrm{L}$ ampicillin at $37{ }^{\circ} \mathrm{C}$ to an $\mathrm{OD}_{600}$ of 0.65 . The cells were induced by the addition of 100 $\mu \mathrm{M}$ isopropyl- $\beta$-D-thiogalactoside and grown at $30{ }^{\circ} \mathrm{C}$ for an additional $5 \mathrm{~h}$. Cells were harvested by centrifugation and suspended in $150 \mathrm{~mL}$ of a lysis buffer containing $20 \mathrm{mM}$ Tris- $\mathrm{HCl}(\mathrm{pH} 8.0), 0.5 \mathrm{M} \mathrm{NaCl}, 5 \mathrm{mM}$ imidazole, $1 \%$ Triton X-100, 0.5\% protamine sulfate, $20 \mu \mathrm{g} / \mathrm{mL}$ trypsin inhibitor, $50 \mu \mathrm{g} / \mathrm{mL}$-methylbenzenesulfonyl fluoride, and 70 $\mu \mathrm{g} / \mathrm{mL}$ chicken egg white lysozyme. The cells were lysed by stirring for $30 \mathrm{~min}$ at $4{ }^{\circ} \mathrm{C}$, followed by brief sonication and centrifugation. For the purification of the histidinetagged LuxS, the supernatant was loaded on a Talon metal affinity column (Clontech, 3.0 $\times 2.5 \mathrm{~cm})$ equilibrated in $20 \mathrm{mM}$ Tris- $\mathrm{HCl}(\mathrm{pH} 8.0), 0.5 \mathrm{M} \mathrm{NaCl}$, and $5 \mathrm{mM}$ imidazole. The column was eluted with the above buffer containing $60 \mathrm{mM}$ imidazole. Fractions containing significant amounts of LuxS protein (as analyzed by SDS-PAGE) were pooled and concentrated in an Amicon apparatus (Millipore). Glycerol was added to a final concentration of $33 \%(\mathrm{v} / \mathrm{v})$, and the enzyme was quickly frozen in liquid nitrogen and stored at $-80{ }^{\circ} \mathrm{C}$.

$\boldsymbol{N}, \boldsymbol{N}^{\prime}$-Di(tert-butoxycarbonyl)-L-homocystine (12). ${ }^{[3]}$ To a solution of Lhomocystine $(2.68 \mathrm{~g}, 10.0 \mathrm{mmol})$ in $10 \%$ sodium carbonate solution $(90 \mathrm{~mL})$ and dioxane $(80 \mathrm{~mL})$ was added di-t-butyl dicarbonate $(4.80 \mathrm{~g}, 22.2 \mathrm{mmol})$ in an ice-water bath. The mixture was allowed to warm to room temperature and stirred overnight. The solution was adjusted to $\mathrm{pH} 4$ with $10 \%$ citric acid and extracted with ethyl acetate $(3 \times 50 \mathrm{~mL})$. The organic layers were combined, washed with brine $(2 \times 20 \mathrm{~mL})$, dried over sodium sulfate, and concentrated to give compound 12 as a white solid (4.62 g, 99\%). ${ }^{1} \mathrm{H} \mathrm{NMR}$ $\left(250 \mathrm{MHz}, \mathrm{CD}_{3} \mathrm{OD}\right) \delta 4.20(\mathrm{~m}, 2 \mathrm{H}), 2.74(\mathrm{~m}, 4 \mathrm{H}), 2.20(\mathrm{~m}, 2 \mathrm{H}), 1.96(\mathrm{~m}, 2 \mathrm{H}), 1.42(\mathrm{~s}$, $18 \mathrm{H})$.

$\boldsymbol{N}, N^{\prime}$-Di(tert-butoxycarbonyl)-L-homocystine di(tert-butyl)ester (13). t-Butanol (0.62 g, $8.4 \mathrm{mmol})$ and N,N'-diisopropylcarbodiimide $(1.2 \mathrm{~mL}, 7.6 \mathrm{mmol})$ was stirred overnight in the presence of a catalytic amount of $\mathrm{CuCl}(8 \mathrm{mg})$. The resulting O-t-butyl- 
$\mathrm{N}, \mathrm{N}$ '-diisopropylisourea solution was diluted in dichloromethane $(5 \mathrm{~mL})$ followed by the addition of acid $12(0.37 \mathrm{~g}, 0.79 \mathrm{mmol})$. The mixture was refluxed for 4 days. The precipitate was removed by filtration and the filtrate was evaporated to dryness and purified by flash silica gel chromatography to give the diester $13(0.43 \mathrm{~g}, 94 \%)$ as a white solid. ${ }^{1} \mathrm{H}$ NMR $\left(250 \mathrm{MHz}, \mathrm{CDCl}_{3}\right) \delta 5.22(\mathrm{~d}, \mathrm{~J}=7.5 \mathrm{~Hz}, 2 \mathrm{H}), 4.24(\mathrm{~m}, 2 \mathrm{H}), 2.70(\mathrm{~m}$, $4 \mathrm{H}), 2.19(\mathrm{~m}, 2 \mathrm{H}), 1.97(\mathrm{~m}, 2 \mathrm{H}), 1.48(\mathrm{~s}, 18 \mathrm{H}), 1.45(\mathrm{~s}, 18 \mathrm{H}) ;{ }^{13} \mathrm{C}$ NMR $(63 \mathrm{MHz}$, $\left.\mathrm{CDCl}_{3}\right) \delta 171.5,155.7,82.5,80.1,53.6,34.9,33.1,28.7,28.3$.

N-tert-Butoxycarbonyl-L-homocysteine tert-butyl ester (5). To disulfide 13 (0.43 $\mathrm{g}, 0.74 \mathrm{mmol})$ in DMF $(6 \mathrm{~mL})$ was added water $(0.6 \mathrm{~mL})$ and tributylphosphine $(185 \mu \mathrm{L}$, $0.79 \mathrm{mmol})$ followed by stirring overnight under argon. The mixture was diluted with $\mathrm{H}_{2} \mathrm{O}(70 \mathrm{~mL})$ and extracted with ethyl acetate $(3 \times 30 \mathrm{~mL})$. The combined organic layers were washed with brine $(2 \times 20 \mathrm{~mL})$, dried over $\mathrm{Na}_{2} \mathrm{SO}_{4}$, concentrated, and purified by silica gel chromatography. Thiol 5 was obtained as thick oil in quantitative yield. ${ }^{1} \mathrm{H}$ NMR (250 MHz, $\left.\mathrm{CDCl}_{3}\right) \delta 5.17(\mathrm{~d}, \mathrm{~J}=6.9 \mathrm{~Hz}, 1 \mathrm{H}), 4.29(\mathrm{~m}, 1 \mathrm{H}), 2.55(\mathrm{~m}, 2 \mathrm{H}), 2.06(\mathrm{~m}$, $1 \mathrm{H}), 1.95(\mathrm{~m}, 1 \mathrm{H}), 1.55(\mathrm{t}, \mathrm{J}=5.0 \mathrm{~Hz}, 1 \mathrm{H}), 1.47(\mathrm{~s}, 9 \mathrm{H}), 1.45(\mathrm{~s}, 9 \mathrm{H}) ;{ }^{13} \mathrm{C} \mathrm{NMR}(63$ $\left.\mathrm{MHz}, \mathrm{CDCl}_{3}\right) \delta 171.7,155.8,82.5,80.1,53.3,37.9,28.7,28.3,21.1$.

Allyl 2,3,5-tris(p-methoxybenzyl)-D-lyxofuranoside (3). D-Lyxose (1.15 g, 7.5 mmol) was dissolved in allyl alcohol $(20 \mathrm{~mL})$ and concentrated $\mathrm{H}_{2} \mathrm{SO}_{4}(0.15 \mathrm{~mL})$ was added. The solution was stirred overnight at room temperature. Amberlite resin $\left(\mathrm{OH}^{-}\right.$ form) was added to neutralize the solution. The resin was removed by filtration and rinsed with methanol $(3 \times 10 \mathrm{~mL})$. The combined solutions were concentrated to dryness. The residue was dissolved in THF $(30 \mathrm{~mL})$, and 50\% KOH $(25 \mathrm{~mL})$, p-methoxybenzyl chloride $(7.8 \mathrm{~mL}, 49.5 \mathrm{mmol})$ and tetrabutylammonium bromide $(100 \mathrm{mg})$ were added. The mixture was refluxed for $6 \mathrm{~h}$ with vigorous stirring, cooled to room temperature, and diluted with $\mathrm{H}_{2} \mathrm{O}(100 \mathrm{~mL})$. The solution was extracted with ethyl acetate $(3 \times 40 \mathrm{~mL})$ and the organic layers were combined, washed with brine $(2 \times 20 \mathrm{~mL})$, dried over $\mathrm{Na}_{2} \mathrm{SO}_{4}$, concentrated under vacuum, and purified by silica gel chromatography to give the glycoside 3 as a mixture of $\alpha / \beta$ anomers $(2.90 \mathrm{~g}, 76 \%$ yield $) .{ }^{1} \mathrm{H}$ NMR $(250 \mathrm{MHz}$, $\left.\mathrm{CDCl}_{3}\right) \delta 7.28-7.17(\mathrm{~m}, 6 \mathrm{H}), 6.92-6.84(\mathrm{~m}, 6 \mathrm{H}), 5.86(\mathrm{~m}, 1 \mathrm{H}), 5.28-5.12(\mathrm{~m}, 2 \mathrm{H}), 4.66-$ 3.46 (complex m, 14H), $3.79(\mathrm{~s}, 9 \mathrm{H})$. HRESI-MS: $\mathrm{C}_{32} \mathrm{H}_{38} \mathrm{O}_{8} \mathrm{Na}^{+}\left([\mathrm{M}+\mathrm{Na}]^{+}\right)$, calcd 573.2459, found 573.2483.

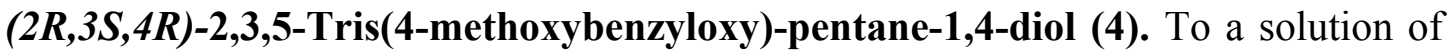
glycoside 3 (0.27 g, $0.49 \mathrm{mmol})$ and di[1,3-bis(diphenylphosphino)propane]dichloronickel ( II ) $(8 \mathrm{mg})$ in diethyl ether $(10 \mathrm{~mL})$ was added DIBAL (1.0 M in THF, 0.74 mmol) at $0{ }^{\circ} \mathrm{C}$. After stirring for $2 \mathrm{~h}, 5 \mathrm{~mL}$ of water was added followed by $10 \%$ citric acid $(20 \mathrm{~mL})$ and then diethyl ether $(40 \mathrm{~mL})$. The ethereal layer was separated and the aqueous phase was extracted with ether $(2 \times 30 \mathrm{~mL})$. The combined organic layers were washed with $\mathrm{H}_{2} \mathrm{O}(20 \mathrm{~mL})$, dried over $\mathrm{Na}_{2} \mathrm{SO}_{4}$, and concentrated to dryness. The residue was dissolved in ethanol $(10 \mathrm{~mL})$ and $\mathrm{NaBH}_{4}(34 \mathrm{mg}, 0.98 \mathrm{mmol})$ was added and the solution was stirred until the starting material was consumed (about $30 \mathrm{~min}$ ). The mixture was diluted with $\mathrm{H}_{2} \mathrm{O}(50 \mathrm{~mL})$ and extracted with ethyl acetate $(2 \times 30 \mathrm{~mL})$. Diol 4 was purified by silica gel chromatography to afford a thick oil (182 mg, 73\% yield). ${ }^{1} \mathrm{H} \mathrm{NMR}$ 
$\left(400 \mathrm{MHz}, \mathrm{CDCl}_{3}\right) \delta$ 7.26-7.15 (m, 6H), $6.85(\mathrm{~m}, 6 \mathrm{H}), 4.61(\mathrm{~d}, \mathrm{~J}=10.8 \mathrm{~Hz}, 1 \mathrm{H}), 4.51(\mathrm{~s}$, 2H), $4.44(\mathrm{~d}, \mathrm{~J}=7.2 \mathrm{~Hz}, 1 \mathrm{H}), 4.42(\mathrm{~d}, \mathrm{~J}=7.2 \mathrm{~Hz}, 1 \mathrm{H}), 4.37(\mathrm{~d}, \mathrm{~J}=10.8 \mathrm{~Hz}, 1 \mathrm{H}), 3.96$ (m, $1 \mathrm{H}), 3.83-3.65$ (m, 5H), 3.50-3.39 (m, 2H), 3.74 (s, 9H), 2.87 (brs, 1H), 2.65 (brs, 1H); ${ }^{13} \mathrm{C} \mathrm{NMR}\left(100 \mathrm{MHz}, \mathrm{CDCl}_{3}\right) \delta 159.4,130.2,130.1,130.0,129.6,114.0,79.4,73.9,73.1$, 72.1, 71.1, 69.8, 60.7, 55.3. HRESI-MS: $\mathrm{C}_{29} \mathrm{H}_{36} \mathrm{O}_{8} \mathrm{Na}^{+}\left([\mathrm{M}+\mathrm{Na}]^{+}\right)$, calcd 535.2302, found 535.2335 .

$(4 R, 5 R, 6 R)-5,6-B i s(p-m e t h o x y b e n x y l o x y)-4-(p-m e t h o x y b e n z y l o x y m e t h y l)-[1,3,2]$ dioxathiepane 2,2-dioxide (6). To a solution of diol 4 (146 $\mathrm{mg}, 0.28 \mathrm{mmol}$ ) and triethylamine $(160 \mu \mathrm{L}, 1.14 \mathrm{mmol})$ in dichloromethane $(12 \mathrm{~mL})$ was added thionyl chloride $\left(42 \mu \mathrm{L}, 0.57 \mathrm{mmol}\right.$ ) at $-78{ }^{\circ} \mathrm{C}$. The mixture was allowed to warm to $0{ }^{\circ} \mathrm{C}$ and stirred until the reaction was completed $(2.5 \mathrm{~h})$. The reaction mixture was diluted in ethyl acetate $(60 \mathrm{~mL})$, washed with $\mathrm{H}_{2} \mathrm{O}(2 \times 20 \mathrm{~mL})$, dried over $\mathrm{Na}_{2} \mathrm{SO}_{4}$, and concentrated to dryness. The residue was dissolved in $\mathrm{CCl}_{4}(4 \mathrm{~mL})$ and $\mathrm{CH}_{3} \mathrm{CN}(4 \mathrm{~mL})$. To the resulting solution was added $\mathrm{H}_{2} \mathrm{O}(6 \mathrm{~mL})$ followed by $\mathrm{RuCl}_{3}$ hydrate $(2 \mathrm{mg})$ and $\mathrm{NaIO}_{4}(90 \mathrm{mg}$, $0.42 \mathrm{mmol})$ at $0{ }^{\circ} \mathrm{C}$. The mixture was stirred for $1 \mathrm{~h}$, diluted in ethyl acetate $(30 \mathrm{~mL})$, washed with $\mathrm{H}_{2} \mathrm{O}(2 \times 20 \mathrm{~mL})$, dried over $\mathrm{Na}_{2} \mathrm{SO}_{4}$, and concentrated in vacuo. Flash chromatography on silica gel gave the cyclic sulfate (138 mg, 86\% yield). ${ }^{1} \mathrm{H}$ NMR (250 $\left.\mathrm{MHz} \mathrm{CDCl}_{3}\right) \delta$ 7.26-7.16 (m, 6H), $6.87(\mathrm{~m}, 6 \mathrm{H}), 4.83(\mathrm{~d}, \mathrm{~J}=11.1 \mathrm{~Hz}, 1 \mathrm{H}), 4.66-4.56$ $(\mathrm{m}, 4 \mathrm{H}), 4.53(\mathrm{~d}, \mathrm{~J}=11.1 \mathrm{~Hz}, 1 \mathrm{H}), 4.38(\mathrm{~d}, \mathrm{~J}=11.5 \mathrm{~Hz}, 1 \mathrm{H}), 4.30(\mathrm{~d}, \mathrm{~J}=11.5 \mathrm{~Hz}, 1 \mathrm{H})$, $4.12(\mathrm{~m}, 1 \mathrm{H}), 4.05(\mathrm{~m}, 1 \mathrm{H}), 3.89-3.70(\mathrm{~m}, 1 \mathrm{H}), 3.80(\mathrm{~s}, 3 \mathrm{H}), 3.78(\mathrm{~s}, 3 \mathrm{H}), 3.77(\mathrm{~s}, 3 \mathrm{H})$, 3.60-3.46 (m, 2H); ${ }^{13} \mathrm{C}$ NMR $\left(63 \mathrm{MHz}, \mathrm{CDCl}_{3}\right) \delta 160.1,160.0,159.8,130.3,130.1$, 129.8, 129.7, 129.5, 114.5, 114.4, 114.2, 80.9, 78.6, 75.3, 73.6, 72.6, 67.5, 67.1, 55.7. HRESI-MS: $\mathrm{C}_{29} \mathrm{H}_{34} \mathrm{O}_{10} \mathrm{SNa}^{+}\left([\mathrm{M}+\mathrm{Na}]^{+}\right)$, calcd 597.1765, found 597.1797.

2S-tert-Butoxycarbonylamino-4-[(2S,3S,4R)-2,3,5-tris(p-methoxybenzyloxy)-4hydroxypentane-1-mercaptan]-butyric acid tert-butyl ester (7). To a solution of thiol 5 (70 mg, $0.24 \mathrm{mmol})$ in DMF (4 mL) was added n-BuLi (1.6 M in hexane, $0.14 \mathrm{mmol})$ at $0{ }^{\circ} \mathrm{C}$. After stirring for $5 \mathrm{~min}$ a solution of the cyclic sulfate $6(67 \mathrm{mg}, 0.12 \mathrm{mmol})$ in DMF ( $1 \mathrm{~mL}$ ) was added. The mixture was stirred for $\sim 2 \mathrm{~h}$, diluted with ethyl acetate (30 $\mathrm{mL})$, and washed with $\mathrm{H}_{2} \mathrm{O}(2 \times 20 \mathrm{~mL})$. The organic layer was dried over $\mathrm{Na}_{2} \mathrm{SO}_{4}$ and concentrated to dryness. The residue was dissolved in THF $(3 \mathrm{~mL})$ and concentrated $\mathrm{H}_{2} \mathrm{SO}_{4}(2 \mu \mathrm{L})$ and $\mathrm{H}_{2} \mathrm{O}(2 \mu \mathrm{L})$ were added. The mixture was stirred for $\sim 2 \mathrm{~h}$ and then partitioned between ethyl acetate $(30 \mathrm{~mL})$ and $\mathrm{H}_{2} \mathrm{O}(20 \mathrm{~mL})$ containing $5 \% \mathrm{NaHCO}_{3}$ solution $(1 \mathrm{~mL})$. The organic layer was separated, extracted with $\mathrm{H}_{2} \mathrm{O}(2 \times 20 \mathrm{~mL})$, dried over $\mathrm{Na}_{2} \mathrm{SO}_{4}$ and concentrated under vacuum. Silica gel chromatography gave $70 \mathrm{mg}$ (74\%) of a mixture of alcohol 7 and a minor isomer 8 (7:8 =4:1). ${ }^{1} \mathrm{H}$ NMR $(400 \mathrm{MHz}$, $\left.\mathrm{CDCl}_{3}\right) \delta 7.27-7.17(\mathrm{~m}, 6 \mathrm{H}), 6.87-6.83(\mathrm{~m}, 6 \mathrm{H}), 5.10(\mathrm{~d}, \mathrm{~J}=7.6 \mathrm{~Hz}, 1 \mathrm{H}), 4.62-4.38(\mathrm{~m}$, $6 \mathrm{H}), 4.25(\mathrm{~m}, 1 \mathrm{H}), 3.97(\mathrm{~m} 1 \mathrm{H}), 3.84-3.70(\mathrm{~m}, 11 \mathrm{H}), 3.48-3.44(\mathrm{~m}, 1.6 \mathrm{H}), 3.15(\mathrm{~m}$, $0.4 \mathrm{H}), 2.83-2.77(\mathrm{~m}, 2 \mathrm{H}), 2.70(\mathrm{~m}, 0.4 \mathrm{H}), 2.56-2.53(\mathrm{~m}, 1.6 \mathrm{H}), 2.04(\mathrm{~m}, 1 \mathrm{H}), 1.86(\mathrm{~m}$, $1 \mathrm{H}), 1.70(\mathrm{~s}, 1 \mathrm{H}), 1.45(\mathrm{~s}, 9 \mathrm{H}), 1.43(\mathrm{~s}, 9 \mathrm{H})$; HRESI-MS: $\mathrm{C}_{42} \mathrm{H}_{59} \mathrm{NO}_{11} \mathrm{SNa}^{+}\left([\mathrm{M}+\mathrm{Na}]^{+}\right)$, calcd 808.3701, found 808.3686.

2S-tert-Butoxycarbonylamino-4-[(2S,3R)-2,3,5-tris(p-methoxybenzyloxy)-4-oxopentane-1-mercaptan]-butyric acid tert-butyl ester (9). To a solution of Dess-Martin Periodinane (DMP) (40 mg, $95 \mathrm{mmol})$ in dichloromethane $(4 \mathrm{~mL})$ was added the mixture 
of alcohols 7 and 8 (50 mg, $64 \mathrm{mmol})$ dissolved in dichloromethane (1 mL). The solution was stirred at room temperature for $1.5 \mathrm{~h}$ during which a white precipitate was formed. At this point, $10 \% \mathrm{Na}_{2} \mathrm{~S}_{2} \mathrm{O}_{3}(5 \mathrm{~mL})$ and $5 \% \mathrm{NaHCO}_{3}(5 \mathrm{~mL})$ solutions were added. The mixture was stirred until the solid disappeared, and was extracted with ethyl acetate (30 $\mathrm{mL})$. Silica gel chromatography afforded the desired ketone 9 (38 mg, 76\% yield) and a small amount of aldehyde $\mathbf{1 0}(10 \mathrm{mg})$ in pure forms. For $\mathbf{9},{ }^{1} \mathrm{H} \mathrm{NMR}\left(250 \mathrm{MHz}, \mathrm{CDCl}_{3}\right)$ $\delta$ 7.26-7.14 (m, 6H), 6.87-6.82 (m, 6H), $5.08(\mathrm{~d}, \mathrm{~J}=6.8 \mathrm{~Hz}, 1 \mathrm{H}), 4.56-4.36(\mathrm{~m}, 6 \mathrm{H})$, $4.28(\mathrm{~s}, 2 \mathrm{H}), 4.16(\mathrm{~d}, \mathrm{~J}=4.0 \mathrm{~Hz}, 1 \mathrm{H}), 3.92(\mathrm{~m}, 1 \mathrm{H}), 3.79(\mathrm{~s}, 9 \mathrm{H}), 2.76(\mathrm{~d}, \mathrm{~J}=6.1 \mathrm{~Hz}, 2 \mathrm{H})$, $2.50(\mathrm{~m}, 2 \mathrm{H}), 2.01(\mathrm{~m}, 1 \mathrm{H}), 1.85(\mathrm{~m}, 1 \mathrm{H}), 1.71(\mathrm{~m}, 1 \mathrm{H}), 1.49(\mathrm{~s}, 9 \mathrm{H}), 1.44(\mathrm{~s}, 9 \mathrm{H}) ;{ }^{13} \mathrm{C}$ NMR $\left(63 \mathrm{MHz}, \mathrm{CDCl}_{3}\right) \delta 207.7,171.7,160.0,159.8,130.2,130.1,130.0,129.6,114.3$, $114.2,82.7,82.5,80.0,74.4,73.2,72.8,55.7,53.8,33.3,32.8,29.1,28.7,28.4$. HRESIMS: $\mathrm{C}_{42} \mathrm{H}_{57} \mathrm{NO}_{11} \mathrm{SNa}^{+}\left([\mathrm{M}+\mathrm{Na}]^{+}\right)$, calcd 806.3545, found 806.3481. For 10 (containing some 9), ${ }^{1} \mathrm{H}$ NMR $\left(250 \mathrm{MHz}, \mathrm{CDCl}_{3}\right) \delta 9.60(\mathrm{~s}, 1 \mathrm{H}), 7.22(\mathrm{~m}, 4 \mathrm{H}), 7.09(\mathrm{~d}, \mathrm{~J}=8.5 \mathrm{~Hz}$, 2H), $6.84(\mathrm{~m}, 6 \mathrm{H}), 5.10(\mathrm{~d}, \mathrm{~J}=6.4 \mathrm{~Hz}, 1 \mathrm{H}), 4.63(\mathrm{~s}, 2 \mathrm{H}), 4.52-4.37(\mathrm{~m}, 4 \mathrm{H}), 4.20(\mathrm{~m}$ $1 \mathrm{H}), 4.16(\mathrm{~m}, 1 \mathrm{H}), 3.96(\mathrm{~d}, \mathrm{~J}=2.7,9.0 \mathrm{~Hz}, 1 \mathrm{H}), 3.79(\mathrm{~s}, 9 \mathrm{H}), 3.68(\mathrm{~m}, 2 \mathrm{H}), 3.02(\mathrm{~m}, 1 \mathrm{H})$, 2.66-2.47 (m, 2H), $1.99(\mathrm{~m}, 1 \mathrm{H}), 1.80(\mathrm{~m}, 1 \mathrm{H}), 1.45(\mathrm{~s}, 9 \mathrm{H}), 1.44(\mathrm{~s}, 9 \mathrm{H})$.

$2 S$-Amino-4-[(2S,3R)-2,3,5-trihydroxy-4-oxo-pentanemercaptan]butyric acid (1). Ketone 9 (33 mg) was treated with trifluoroacetic acid containing $10 \%$ anisole $(2 \mathrm{~mL})$ at room temperature for $6 \mathrm{~h}$. The volatile solvents were removed by evaporation, and the residue was dissolved in $\mathrm{H}_{2} \mathrm{O}(3 \mathrm{~mL})$ and washed with dichloromethane $(3 \times 2 \mathrm{~mL})$. The aqueous solution was evaporated to give the ketone intermediate $\mathbf{1}$ as a trifluoroacetate salt (15 mg, 93\% yield). ${ }^{1} \mathrm{H}$ NMR (400 MHz, $\left.\mathrm{D}_{2} \mathrm{O}\right) \delta 4.57(\mathrm{~d}, \mathrm{~J}=19.4 \mathrm{~Hz}, 1 \mathrm{H}), 4.50$ (d, J $=19.4 \mathrm{~Hz}, 1 \mathrm{H}), 4.21(\mathrm{~d}, \mathrm{~J}=4.7 \mathrm{~Hz}, 1 \mathrm{H}), 4.02(\mathrm{~m}, 1 \mathrm{H}), 3.97(\mathrm{~m}, 1 \mathrm{H}), 2.81-2.65(\mathrm{~m}, 4 \mathrm{H})$, $2.22(\mathrm{~m}, 1 \mathrm{H}), 2.09(\mathrm{~m}, 1 \mathrm{H}) ;{ }^{13} \mathrm{C} \mathrm{NMR}\left(150 \mathrm{MHz}, \mathrm{D}_{2} \mathrm{O}\right) \delta 212.5,172.6,77.1,71.5,66.7$, 52.6, 33.2, 29.8, 27.3. HRESI-MS: $\mathrm{C}_{11} \mathrm{H}_{17} \mathrm{~F}_{3} \mathrm{NO}_{8} \mathrm{~S}^{-}\left([\mathrm{M}+\mathrm{TFA}-\mathrm{H}]^{-}\right)$, calcd, 380.0627, found 380.0626 .

LuxS Activity Assay. The activity assay for LuxS reaction (total volume $=1 \mathrm{~mL}$ ) was performed in a buffer containing $50 \mathrm{mM}$ HEPES ( $\mathrm{pH} 7.0$ ), $150 \mathrm{mM} \mathrm{NaCl}$, and 150 $\mu \mathrm{M}$ 5,5'-dithio-bis-(2-nitrobenzoic acid) (Ellman's reagent). The concentration of SRH or ketone 1 varied from 0 to $150 \mu \mathrm{M}$ depending on the different enzyme forms used. The reaction was initiated by the addition of LuxS (final concentration of $4.1 \mu \mathrm{M}$ for the C83D mutant and $2.5 \mu \mathrm{M}$ for all other enzymes) and monitored continuously at $412 \mathrm{~nm}$ in a Perkin-Elmer $\lambda 25$ UV-VIS spectrophotometer at room temperature. The data were fitted into Michaelis-Menten equation using KaleidaGraph 3.6.

Isolation of DHPD derivative (11). Ketone 1 (final concentration $1.0 \mathrm{mM}$ ), $\mathrm{Co}$ (II)LuxS (final concentration of $1.0 \mathrm{mg} / \mathrm{ml}$ ), and 1, 2-phenylenediamine (final concentration of $1.0 \mathrm{mM}$ ) were mixed in a buffer containing $50 \mathrm{mM} \mathrm{NaH} \mathrm{PO}_{4}-\mathrm{Na}_{2} \mathrm{HPO}_{4}(\mathrm{pH} 7.0)$ and $50 \mathrm{mM} \mathrm{NaCl}$ (total reaction volume $=1 \mathrm{~mL}$ ) and incubated at room temperature for $20 \mathrm{~h}$. Additional 1, 2-phenylenediamine was then added to make a final concentration of $2 \mathrm{mM}$ and the $\mathrm{pH}$ of the reaction mixture was adjusted to 4.5 by the addition of $2 \mathrm{M} \mathrm{HCl}$. The resulting solution was incubated for another $20 \mathrm{~h}$. The reaction mixture was extracted with ethyl acetate $(4 \times 0.4 \mathrm{~mL}$ ) and the organic layer was concentrated to $\sim 0.2 \mathrm{~mL}$ under reduced pressure. The crude product was purified by reversed-phase HPLC on a semi- 
preparative $\mathrm{C}-18$ column $\left(\mathrm{Vydac}^{\mathrm{TM}}\right)$. The column was eluted with a 30-min gradient of $10-100 \%$ acetonitrile in water (monitored at $240 \mathrm{~nm}$ ). The desired product eluted at $\sim 40 \%$ acetonitrile. ${ }^{1} \mathrm{H}$ NMR $\left(250 \mathrm{MHz}, \mathrm{CDCl}_{3}\right) \delta 8.00-8.04(\mathrm{~m}, 2 \mathrm{H}$, aromatic), 7.70$7.75\left(\mathrm{~m}, 2 \mathrm{H}\right.$, aromatic), $5.10\left(\mathrm{dd}, 1 \mathrm{H}, \mathrm{C} 2^{\prime}-\mathrm{H}, \mathrm{J}=5.5,3.5 \mathrm{~Hz}\right), 4.03\left(\mathrm{dd}, 1 \mathrm{H}, \mathrm{Cl}{ }^{\prime}-\mathrm{H}, \mathrm{J}=\right.$ $11.5,3.5 \mathrm{~Hz}), 3.83\left(\mathrm{dd}, 1 \mathrm{H}, \mathrm{Cl}{ }^{\prime}-\mathrm{H}, \mathrm{J}=11.5,5.5 \mathrm{~Hz}\right), 2.80\left(\mathrm{~s}, 3 \mathrm{H}, \mathrm{CH}_{3}\right)$. HRESI-MS (dissolved in $\left.\mathrm{H}_{2} \mathrm{O}\right): \mathrm{C}_{11} \mathrm{H}_{12} \mathrm{~N}_{2} \mathrm{O}_{2} \mathrm{Na}^{+}\left([\mathrm{M}+\mathrm{Na}]^{+}\right.$), calcd. 227.0791, found 227.0803.

[1] Zhu, J.; Dizin, E.; Hu, X.; Wavreille, A.; Park, J.; Pei, D. Biochemistry 2003, 42, 4717-4726.

[2] Versees, W.; Decanniere, K.; Pelle, R.; Depoorter, J.; Brosens, E.; Parkin, D. W.; Steyaert, J. J. Mol. Biol. 2001, 307, 1363-1379.

[3] Serafinowski, P.; Dorland, E.; Harrap, K. R.; Balzarini, J.; De Clercq, E. J. Med. Chem. 1992, 35, 4576-83. 


\section{${ }^{13} \mathrm{C}$ NMR Spectra: E57D LuxS and $\left[2-{ }^{13} \mathrm{C}\right] \mathrm{SRH}$ (spectra recorded every $16 \mathrm{~min}$ )}

Unknown ketone species

(absent in WT LuxS)

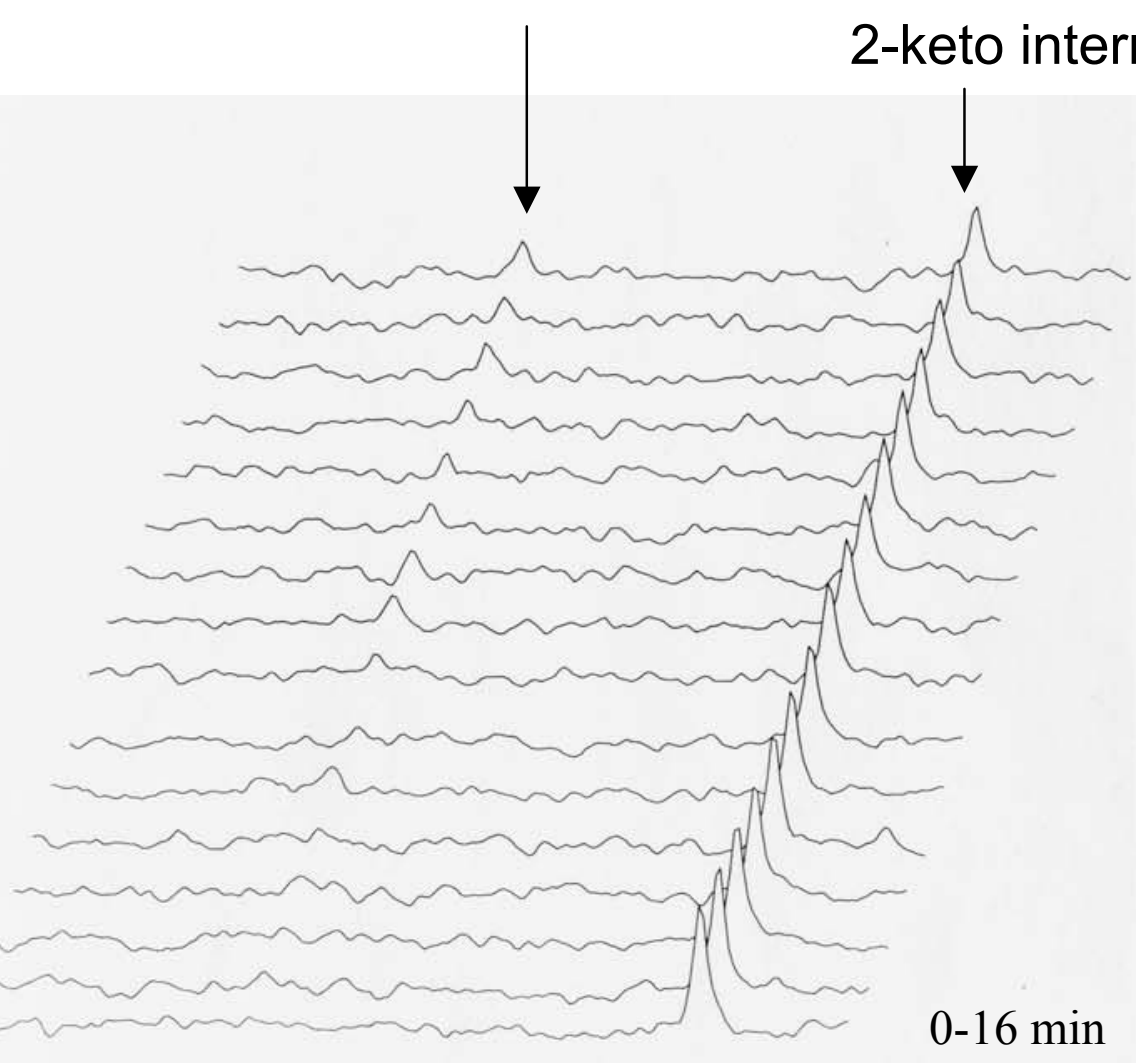

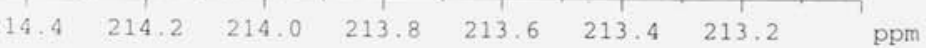

3-keto intermediate

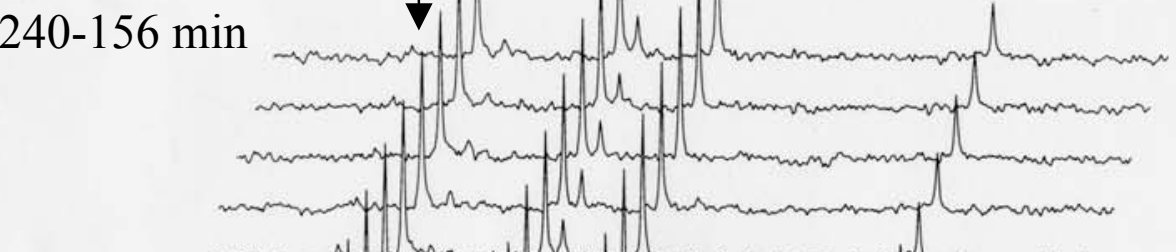




\section{${ }^{13} \mathrm{C}$ NMR Spectra: E57A LuxS and $\left[2-{ }^{13} \mathrm{C}\right] \mathrm{SRH}$ (spectra recorded every $2 \mathrm{~h}$ )}

\section{Unknown ketone species}

(absent in WT LuxS)

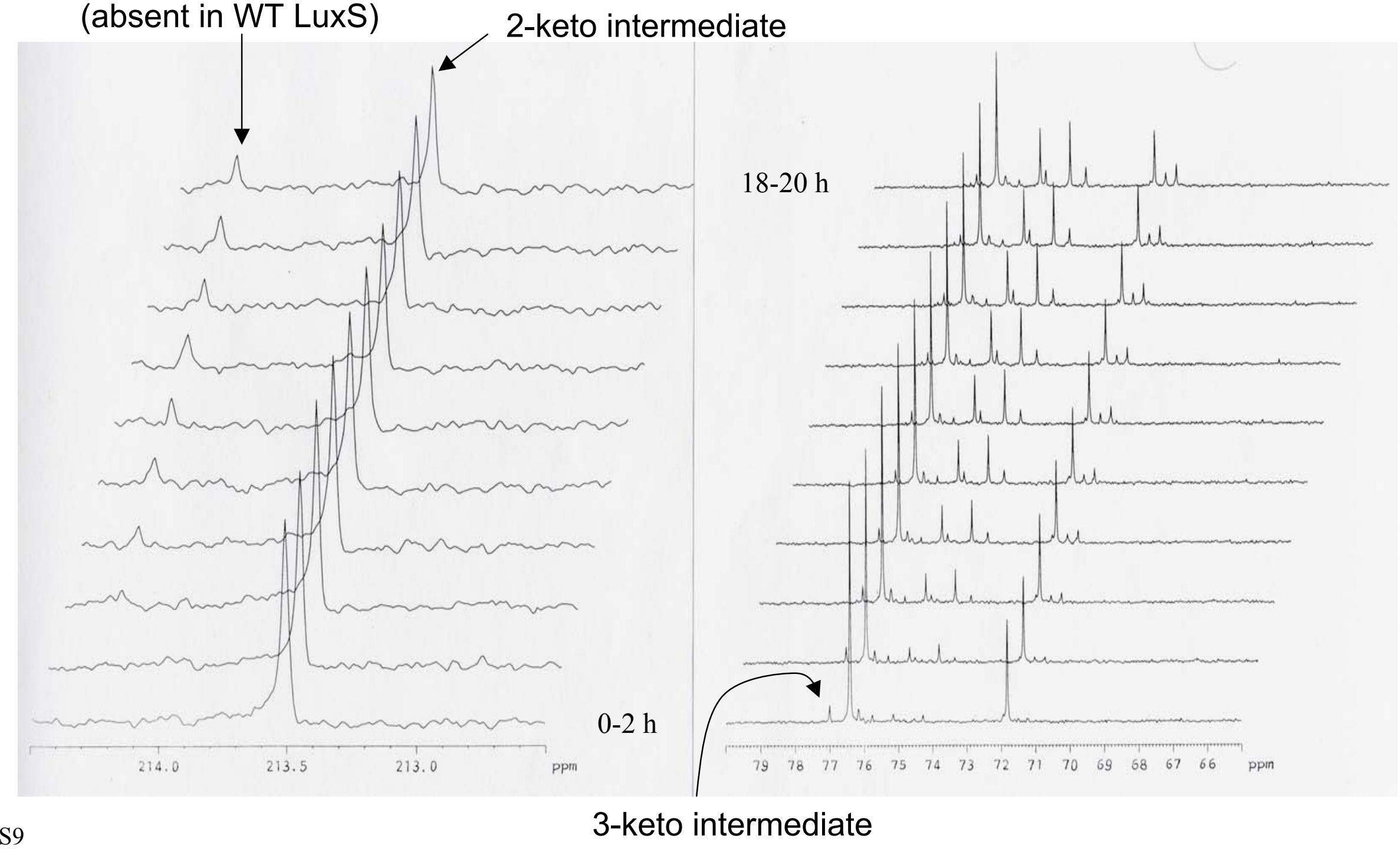




\section{${ }^{13} \mathrm{C}$ NMR Off-Resonance Spectra: WT LuxS and $\left[2-{ }^{13} \mathrm{C}\right] \mathrm{SRH}$}

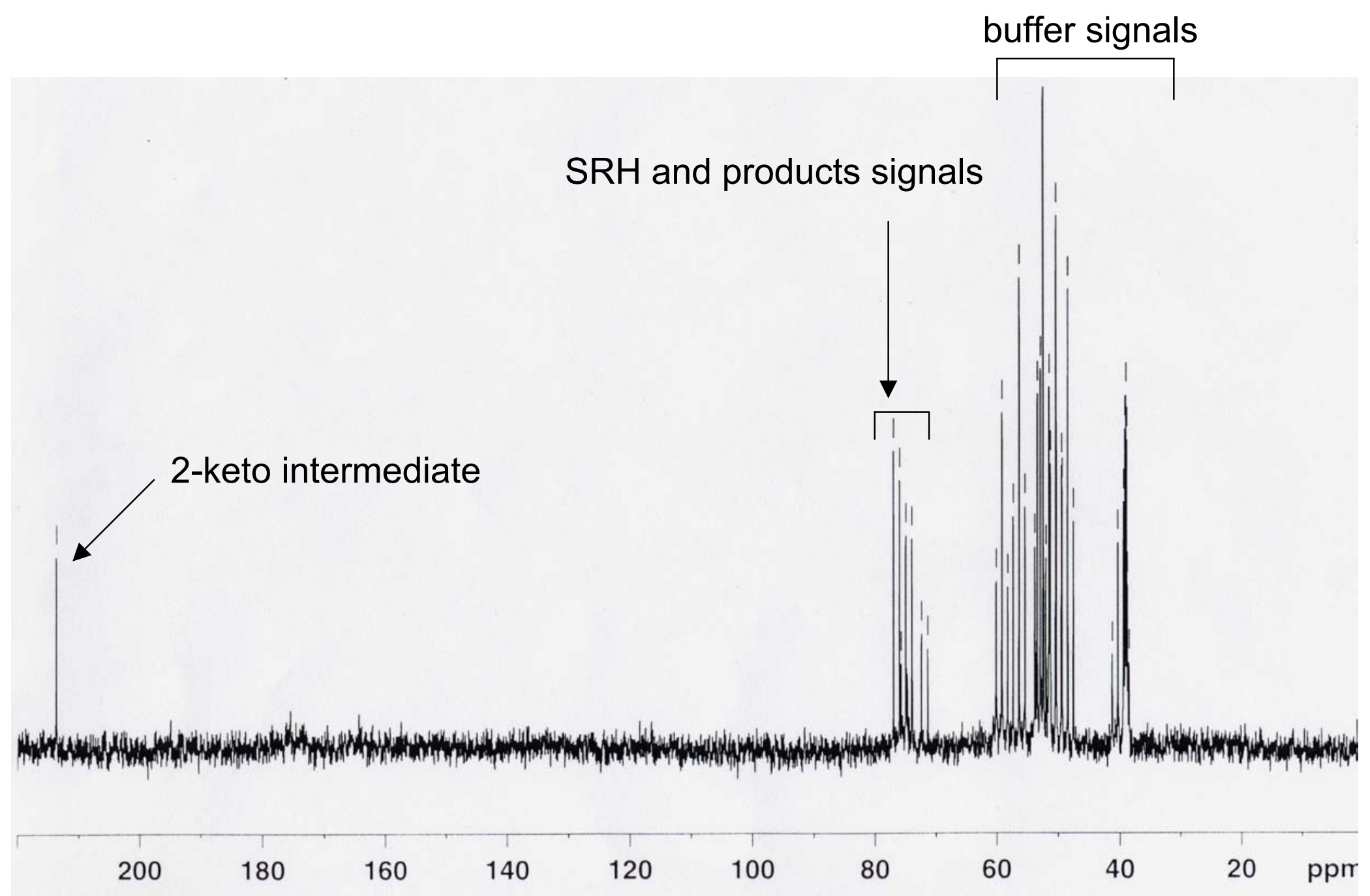




\section{${ }^{13}$ C NMR Spectra: E57D LuxS and $\left[2-{ }^{13} \mathrm{C}\right] \mathrm{SRH}$}

(Reaction was quenched with $\mathrm{MeOH}$ and treated with $\mathrm{NH}_{2} \mathrm{OH}$ prior to $\mathrm{NMR}$ )

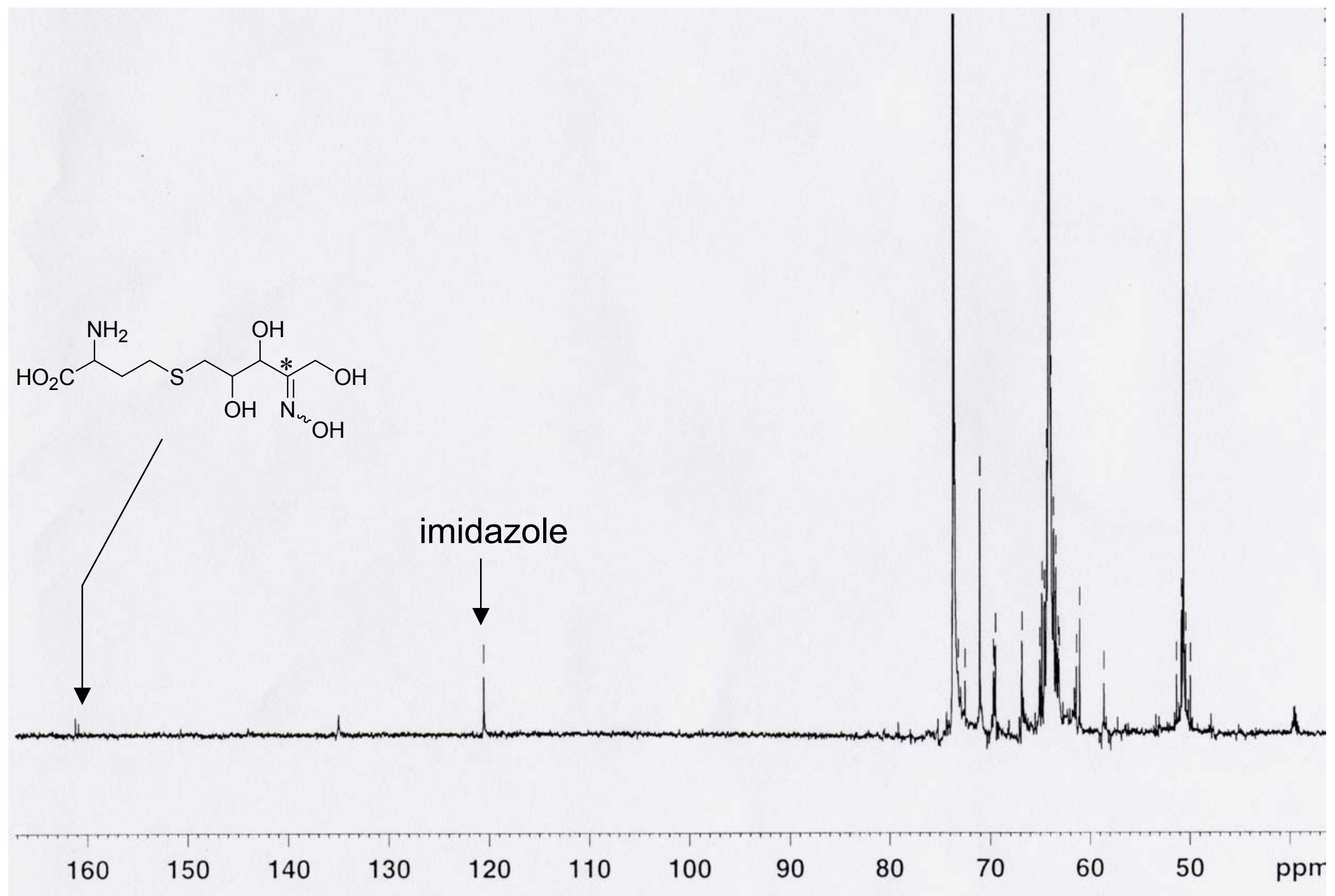




\section{${ }^{13} \mathrm{C}$ NMR Spectra: WT LuxS and $\left[3-{ }^{13} \mathrm{C}\right] \mathrm{SRH}$ (spectra acquired over $2.5 \mathrm{~h}$ )}

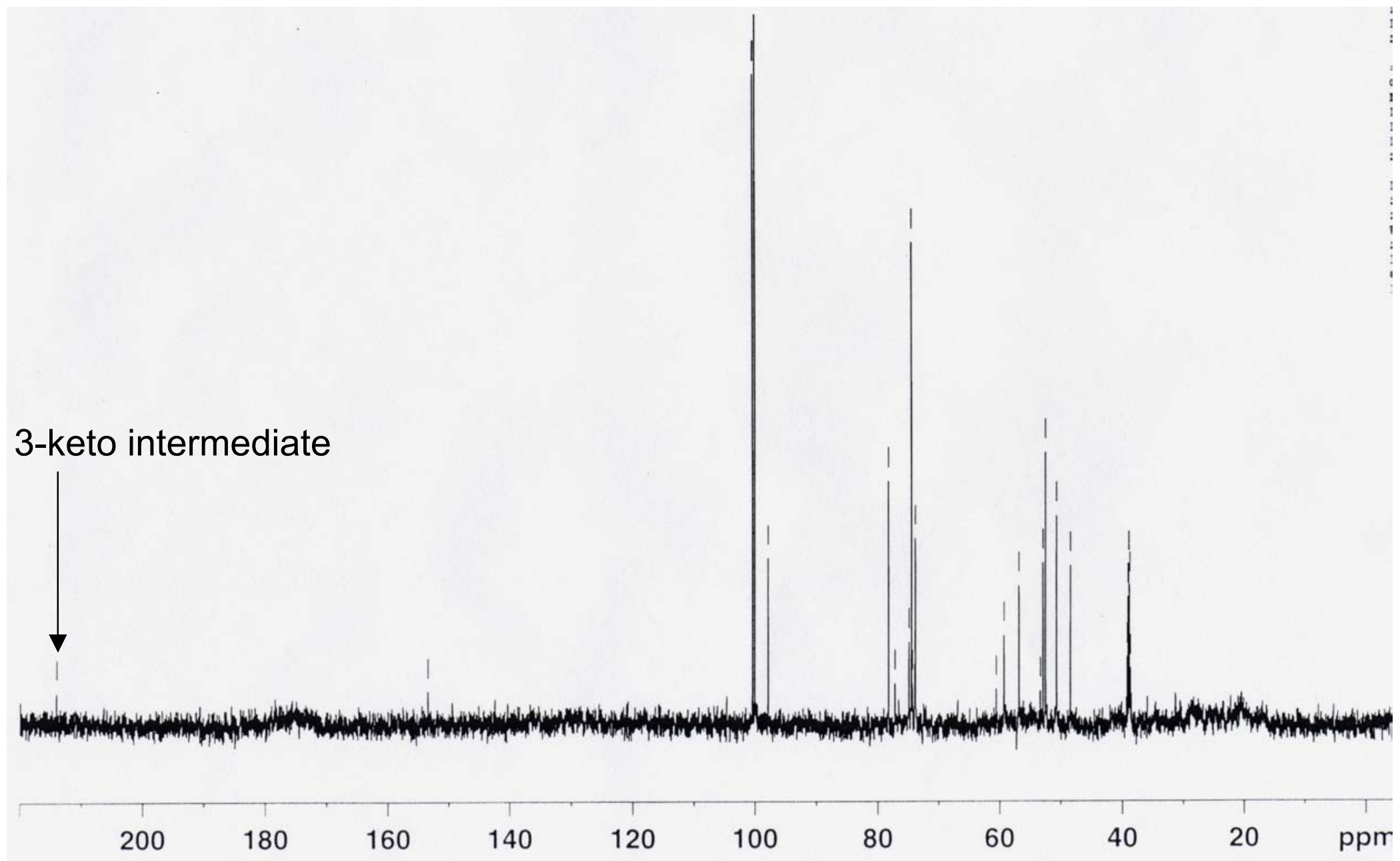




\section{${ }^{13} \mathrm{C}$ NMR Spectra: WT LuxS $(0.6-2.5 \mathrm{mM})$ and $\left[2-{ }^{13} \mathrm{C}\right] \mathrm{SRH}(5.0 \mathrm{mM})$}

(experiment with varying $\mathrm{SRH} / \mathrm{LuxS}$ ratio; spectra recorded every $10 \mathrm{~min}$ )

$[\mathrm{SRH}]=5.0 \mathrm{mM}$ [LuxS $]=2.5 \mathrm{mM}$

$$
[\mathrm{SRH}]=5.0 \mathrm{mM}
$$$$
\text { [LuxS] }=1.2 \mathrm{mM}
$$

$[\mathrm{SRH}]=5.0 \mathrm{mM}$ $[$ LuxS $]=0.6 \mathrm{mM}$

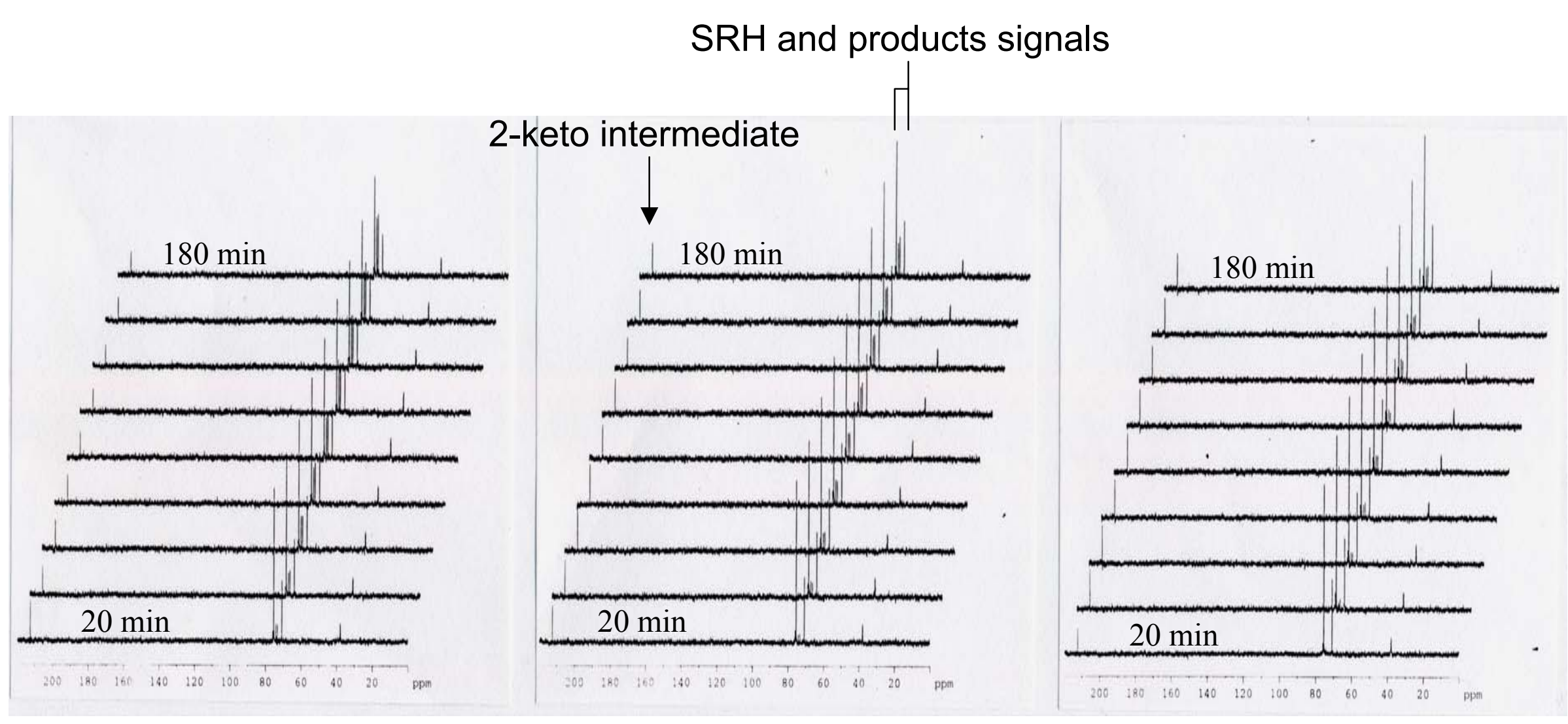




\section{${ }^{13} \mathrm{C}$ NMR Spectra: WT LuxS and $\left[2-{ }^{13} \mathrm{C}\right] \mathrm{SRH}$}

\section{(pulse-chase experiment; spectra recorded every $20 \mathrm{~min}$ )}

$690 \mathrm{~min}$

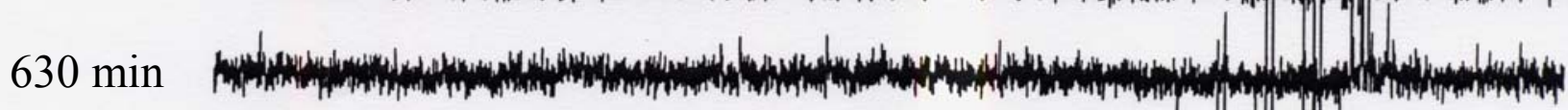
570 min

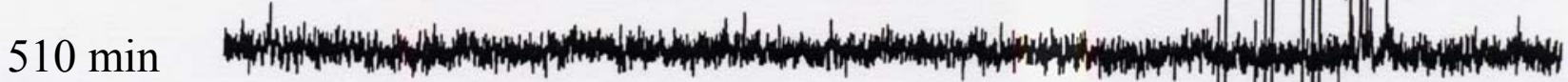

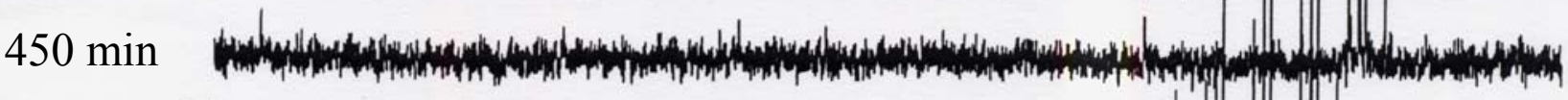

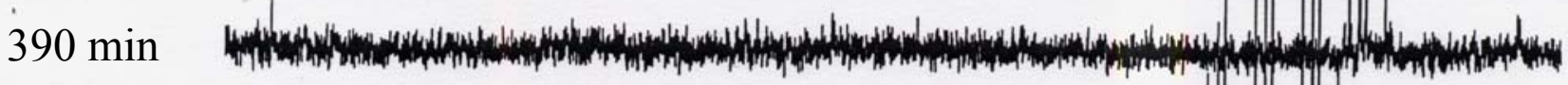
$330 \mathrm{~min} \quad$ ind

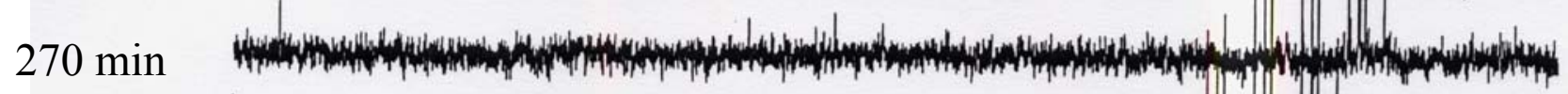

$210 \min$

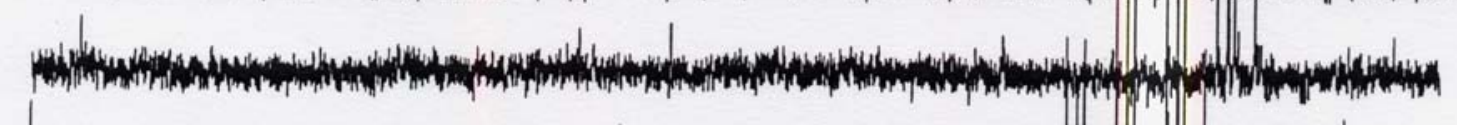

$150 \mathrm{~min}$.

$90 \min$

$30 \mathrm{~min}$

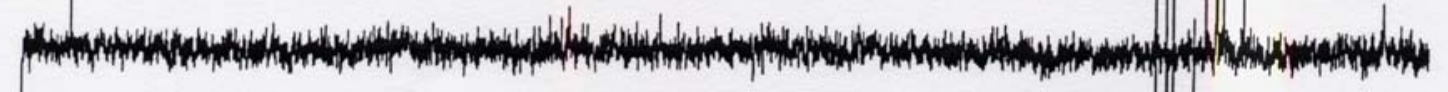

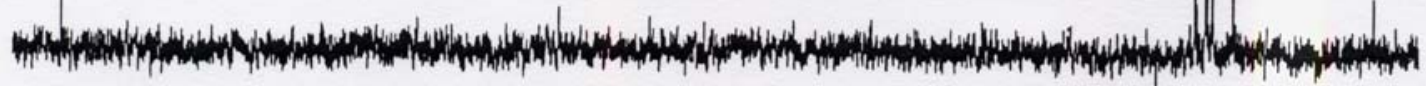

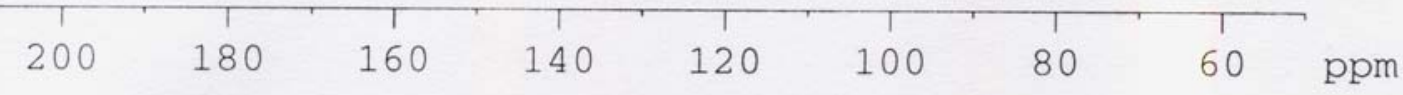

